\title{
Faktor-faktor yang mempengaruhi keinginan orang tua menjadikan anak-anak mereka pegawai dibandingkan berwirausaha (Studi pedagang retail di pasar Bangkinang Kabupaten Kampar)
}

\author{
ARMAN \\ Dosen SekolahTinggiIlmuEkonomiBangkinang
}

\begin{abstract}
Lack of motivation of parents to make their children as an entrepreneur or self-employed is not no excuse. From the results wawacara conducted and analyzed can be found the reason why parents prefer their children to become civil servants compared to become entrepreneurs or self-employed as they (parents) that is running the business opened a shop which is on the market Bangkinang among others: because of the prestige or taste proud parents will be great with the civil servants and the official dress uniform when viewed into a pride, then the certainty of income attributed here that even small payments made to them, but they get certainty. When compared with no certainty though employers can sometimes be great, but sometimes not at all. Also due to old age or retired, retiree becomes a problem for people in this area because the retirement income when it is already limited and sometimes only hope of children who are still not clear as well that the PNS can be no guarantee of that. Then factor can be relied upon, as civil servants or work dikantoran, it will be more reliable in the deal, because the deal sometimes requires a strong and attractive appearance, so to be considered to facilitate civil servants dealing and or become reluctant.
\end{abstract}

Keywords: keingian, Civil Servants, Entrepreneur

\section{PENDAHULUAN}

Permasalahan orang tua tidak menghendaki putra atau putri mereka menjadi petani, pedagang, tukang dan atau profesi biasa menjadi permasalahan tersendiri yang sangat memprihatinkan. Kondisi ini menjadi hal yang dianggap kurang berhasilnya pendidikan putra putrid mereka melanjutkan ke perguruan tinggi. Persepsi orang tua terhadap mereka yang bersekolah tampak pada keberhasilannya masuk menjadi pegawai negeri sipil, atau karyawan bank dan atau perusahaan yang besar dan dengan gaji yang besar dan membanggakan. Jika tidak demikian, maka mereka masih menganggap bahwa pendidikanputra putrid mereka dinilai gagal.

Kota Bangkinang adalah satu salah kota kecil yang terletak di Kabupaten Kampar, di kota ini jika dilihat banyak orang tua yang berjualan di pasar dan membuka took. Toko yang mereka tekuni ini menjual berbagai jenis kebutuhan masyarakat seharihari dan mereka memiliki modal yang relative besar dan bahkan dari data mereka rata-rata mengelola $2-3$ milyar dalam putaran usahanya. Untuk hasil yang dicapai tidak kurang 30 - 50 juta bersih mereka dapatkan dari berjualan tiap bulannya.
Namun orang tua yang berjualan tersebut masih tidak menginginkan putra putri mereka untuk meneruskan usaha mereka, mereka beranggapan bahwa bekerja seperti mereka tidak perlu sekolah tinggi dan hanya membutuhkan pengalaman saja dan hal ini dianggapnya tidak menjadi pekerjaan yang dapat membanggakan. Bila dibandingkan dengan bekerja sebagai PNS (pegawai negeri sipil) yang memiliki gaji rata-rata mereka membawa uang sebulan 2 juta dan bahkan bila mereka masih honor mereka hanya membawa pulang 1 juga rupiah, itu mereka anggap sudah membanggakan dan mereka menganggap pekerjaan tersebut merupakan pekerjaan yang sukses dari pendidikan yang dilakoninya.

Pakaian seragam dan pergi kerja membawa tas menjadi sebuah harapan orang tua kepada putra putri mereka dan apatah lagi nantinya ada harapan bagi orang tua untuk putra putri mereka menjadi pejabat yang akan memiliki kekuasaan di kantornya. Kondisi ini apabila dilihat dari harapan perguruan tinggi dan yang merupakan harapan dari pemerintah dalam mengarahkan pergguruan tingginya menjadi lulusan yang memiliki jiwa kewirausahaan dan berjiwa wirausaha dan hidup mandiri menjadi sangat 
berbeda dari kenyataan yang ada. Selain itu juga jiwa wirausaha menjadi slogan keberanian pada lulusan nantinya.

Sebagaimana dijelaskan oleh beberapa ahli mengenai kewirausahaan seperti menurut Saiman (2009: 42) kewirausahaan adalah halhal atau upaya-upaya yang berkaitan dengan penciptaan kegiatan atau usaha atau aktivitas bisnis atas dasar kemauan sendiri dan atau mendirikan usaha atau bisnis dengan kemauan dan atau kemampuan sendiri. Wirausaha/ wiraswasta adalah orang-orang yang memiliki sifat-sifat kewirausahaan dan umumnya memiliki keberanian dalam mengambil resiko terutama dalam menangani usaha atau perusahaannya dengan berpijak pada kemampuan dan atau kemauan sendiri.

Pendapat lain yang disampaikan Robert D. Hisrich (2005) dalam Saiman (2009: 42) menjelaskan kewirausahaan adalah proses dinamis atau penciptaan tambahan kekayaan. Kekayaan diciptakan oleh individu yang berani mengambil resiko utama dengan syarat-syarat kewajaran, waktu dan atau komitmen karir atau penyediaan nilai untuk berbagai barang dan jasa. Produk dan jasa tersebut tidak akan mungkin baru atau unik, tetapi nilai tersebut bagaimanapun juga harus dipompa wirausahawan dengan penerimaan dan penempatan kebutuhan ketrampilan dan sumber-sumber daya.

MenurutKasmir

(2007

kewirausahaan pertama kali muncul pada abad 18 diawali dengan penemuan-penemuan baru seperti mesin uap, mesin pemintal, dan lainnya. Tujuan utama mereka adalah pertumbuhan dan perluasan organisasi melalui inovasi dan kreativitas. Keuntungan dan kekayaan bukan tujuan utama. Secara sederhana arti wirausahawan (entrepreneur) adalah orang yang berjiwa berani mengambil resiko untuk membuka usaha dalam berbagai kesempatan berjiwa berani mengambil resiko artinya bermental mandiri dan berani memulai usaha, tanpa diliputi rasa takut atau cemas sekalipun dalam kondisi tidak pasti.

Dalam lampiran Keputusan Menteri Koperasi dan Pembinaan Pengusahan Kecil Nomor 961/KEP/M/XI/1995, dicantumkan bahwa: 1) Wirausaha adalah orang yang mempunyai semangat, sikap, perilaku dan kemampuan kewirausahaan; Kewirausahaan adalah semangat, sikap, perilaku dan kemampuan seseorang dalam menangani usaha atau kegiatan yang mengarah pada upaya mencari, menciptakan serta menerapkan cara kerja, teknologi dan produk baru dengan meningkatkan efisiensi dalam rangka memberikan pelayanan yang lebih baik dan atau memperoleh keuntungan yang lebih besar.

Berbicara masalah kewirausahaan dibutuhkan semangat atau motivasi dalam berusaha Miftah Thoha (2008: 207) menjelaskan dorongan ini sebagai bentuk kebutuhan (need), keinginan (want) dan tujuan (goals). Sedangkan menurut Sopiah (2008: 170) menjelaskan kemauan keras berusaha yang ditunjukkan oleh seorang ketika menerapkan usahanya kepada tugastugas pekerjannya. Dengan kemauan yang keras, maka segala usaha yang akan dilakukan dan kegagalan tidak akan membuatnya patah arang untuk terus berusaha sampai tercapainya tujuan. Kemudian arah dan tujuan yaitu arah yang dituju oleh usaha dan kemauan keras yang dimiliki seseorang.

Menurut Ishak Arep (2003: 12) menjelaskan seseorang bekerja didorong oleh bermacam-macam ada yang termotivasi mengerjakan sesuatu karena uangnya banyak, karena rasa aman, prestise. Konsep motivasi adalah self concept realization, yaitu merealisasikan konsep dirinya atau seseorang akan termotivasi jika: 1) ia hidup dalam suatu cara yang sesuai dengan peran yang ia sukai, 2) diperlakuan sesuai dengan tingkatan yang lebih ia sukai, 3) dihargai dengan cara yang mencerminkan penghargaan atas kemampuannya. Pentingnya motivasi perlu dilakukan ketika perasaan tak puas muncul dipermukaan, sebagai bentuk dorongan untuk mencapai keinginannya. Faktor-faktor yang mempengaruhi motivasi antara lain kesempatan, pekerjaan itu sendiri, pengakuan, pengembangan.

Menurut Taliziduhu Ndraha (2005: 14) menjelaskan dorongan erat kaitannya dengan keinginan (want) yang terarah pada 
alat-alat yang dianggap dapat mendukung kehidupan disebut kebutuhan, dahulu alat yang dapat digunakan untuk memenuhi kebutuhan itu disebut dengan barang dan jasa. Dewasa ini kebutuhan manusia semakin jelas dan berkembang. Jasa dibedakan dengan layanan; sementara itu kepedulian terhadap sesama dan lingkungan juga dipandang sebagai kebutuhan.

Menurut An. Ubaedy (2007: 20) motivasi berwirausaha adalah sesuatu yang dipikirkan orang secara konsisten atau sesuatu yang mendorong orang untuk melakukan sesuatu untuk meraih prestasi, kebiasaannya proaktif, punya tujuan, punya prioritas, menemukan solusi, kemampuan memahami, bersinerji dan mengasah gergaji.

Menurut McClelland dalam Thoha (2008: 236) seseorang dianggap memiliki motivasi untuk berprestasi jika dia memiliki keinginan untuk melakukan suatu karya yang berprestasi lebih baik dari prestasi karya orang lain. Menurut Saiman (2009: 26) motivasi berprestasi antara lain dapat dilihat dari: laba (dapat menentukan berapa laba yang dihendaki, keuntungan yang diterima, dan berapa yang akan dibayarkan kepada pihak lain atau pegawainya); kebebasan (mengatur waktu, bebas dari supervise, bebas aturan main yang menekan, bebas dari aturan budaya organisasi); impian personal (mencapai standar hidup yang diharapkan, lepas dari rutinitas kerja yang membosankan, imbalan); kemandirian (memiliki rasa bangga, mandiri dalam pengawasan dan menjadi menejer terhadap diri sendiri).

Menurut Ishak Arep dan Hendri Tanjung (2003: 122) menjelaskan motivasi berwirausaha adalah prestasi sebagai sumber motivasi, semakin tinggi tingkat motivasi berprestasi dari beberapa eksekutif, semakin meningkat posisinya dalam jabatannya. Menurut David C McClelland (1987: 86) faktor-faktor yang mempengaruhi motivasi berprestasi, a) ras, b) lingkungan, c) cara mengasuh anak; d) nilai keagamaan.

Berdasarkan uraian di atas, maka dapat disimpulkan kewirausahaan adalah usaha-usaha yang dilakukan dalam bentuk motivasi, semangat, sikap, perilaku dan kemampuan seseorang dalam menangani usaha atau kegiatan yang mengarah pada upaya mencari, menciptakan serta menerapkan cara kerja, teknologi dan produk baru dengan meningkatkan efisiensi dalam rangka memberikan pelayanan yang lebih baik dan atau memperoleh keuntungan yang lebih besar.

Menurut Leonardus Saiman (2009: 50) kewirausahaan merupakan semangat yang dimiliki seorang usahawan yang semangat kewirausahaan ini perlu dimasyarakatkan dan dibudayakan oleh para pemimpin pada umumnya dan pra pengusaha pada khususnya yang dapat dilihat dari:Kemauan kuat untuk berkarya (utamanya bidang ekonomi) dengan semangat mandiri; Mampu membuat keputusan yang tepat dan berani mengambil resiko; Kreatif dan inovatif; Tekun, teliti dan produktif; Berkarya dengan semangat kebersamaan dan etika bisnis yang sehat.

Berdasarkan uraian terebut, maka dapat disimpulkan bahwa dimensi kewirausahaan antara lain: kemauan kuat untuk berkarya (utamanya bidang ekonomi) dengan semangat mandiri; mampu membuat keputusan yang tepat dan berani mengambil resiko; kreatif dan inovatif; tekun, teliti dan produktif; dan berkarya dengan semangat kebersamaan dan etika bisnis yang sehat.

Permasalahan mengenai sikap atau persepsi dari orang tua meninginkan masuk pegawai negeri dibandingkan dengan menjadi wirausahawan menjadi satu fenomena yang perlu mendapatkan perhatian serius. Hal ini menyebabkan kekecewaan orang tua karena ketersediaan kesempatan kerja menjadi PNS yang semakin ketat dan bahkan hampir tidak mungkin bisa lulus dan juga menyebabkan orang tua enggan menyekolahkan putra dan putri mereka ke jenjang pendidikan tinggi.

Menurut Soekanto (2002: 25) manusia seperti kita ini mempunyai naluri yang kuat untuk hidup bersama dengan sesamanya. Apabila dibandingkan dengan makhluk hidup lain seperti hewan, misalnya, manusia tidak akan mungkin hidup sendiri. Sejak dilahirkan manusia sudah mempunyai 
naluri untuk hidup berkawan. Pada dasarnya manusia mempunyai dua hasrat yang kuat dalam dirinya, yakni: Keinginan untuk menjadi satu dengan sesamanya atau manusia lain di sekelilingnya (misalnya, masyarakat). Keinginan untuk menjadi satu dengan lingkungan alam sekelilingnya.

Kemudian Weber dalam Ritzer (2005: 210) memperkenalkan interaksionisme dengan cara mendefinisikan dan membahas konsep dasar yang menyangkut interaksi seperti tindakan, tindakan sosial, dan tindakan non sosial serta hubungan sosial. Interaksi sosial merupakan suatu proses sosial yang merupakan hubungan timbal balik antara dua atau lebih individu atau kelompok. Interaksi antara individu adalah tindakan sosial dengan menggunakan bahasa, simbol, dan isyarat dan mempunyai hubungan timbal balik terhadap perilaku, harapan dan pikiran.

Konsep 'perilaku' menurut Weber sebenarnya lebih bermakna "diam" dibandingkan dengan perilaku yang tergolong otomatis yang lahir tanpa melalui proses berpikir sebelumnya. Sebuah stimulus yang menimbulkan dan kemudian menjadikannya sebagai bentuk perilaku (tertentu) hanya terjadi, karena adanya sedikit bantuan 'intervening', diantara stimulus dan respon.Oleh karena itu, "perilaku" (behavior) menjadi tidak menarik dan tidak penting untuk diperbincangkan dalam sosiologi Weber.

Menurut Weber dalam Ritzer (2005: 24) menjelaskan tindakan sosial seperti semua tindakan, dapat diorientasikan dalam empat cara: 1) Tipe tindakan sosial yang bersifat rasional instrumental. Yang disebut rasional di sini menunjuk pada cara yang efisien dan efektif. Cara efisien berarti memperhitungkan energi yang dikeluarkan (banyak-sedikit, mahal-murah). Orang itu disebut rasional kalau biaya atau enerji yang dikeluarkan untuk mencapai suatu tujuan itu semurah mungkin, sesuai prinsip ekonomi; 2) Tindakan sosial yang rasional nilai. Nilai itu berhubungan dengan etika, estetika, agama atau apa saja yang berdiri sendiri, atau tidak harus ada kaitannya dengan sesuatu yang bersifat rasional. Baik atau buruk, layak atau tidak layak dalam etika atau agama adalah sesuatu yang diterima begitu saja. Atau indah tidak indahnya suatu seni hampir murni berhubungan dengan perasaan orang yang menikmatinya. Tindakan sosial yang efisien dalam rangka mencapai tujuan itu antara lain tidak membuang-buang waktu dan tenaga yang dapat membelokkan perhatian. Begitu kita menyimpang, diperlukan tenaga, biaya dan waktu untuk dapat kembali ke jalan yang mengarah ke keselamatan itu; 3) Tindakan sosial afektual seringkali disamakan saja dengan tindakan emosional. Tentu tidak ada salahnya. Tindakan sosial afektual itu ditentukan oleh keadaan perasaan khusus si actor; 4) Tindakan sosial itu disebut tradisional kalau perilaku si aktor itu ditentukan oleh kebiasaan yang berlaku dalam masyarakat. Kebiasaan-kebiasaan seperti ini biasanya diterima orang dengan begitu saja (taken for granted). Mengapa seorang anak harus menghormati orang tuanya, karena memang dari dulunya sudah begitu. Kebiasaan itu tidak dipertanyakan, karena pada umumnya orang menganggap kebiasaan itu merupakan sesuatu yang baik, yang karena itu harus dipelihara.

Menurut Ritzer and Douglas (2005: 389) menyebutkan 4 (empat) tahap tindakan yang saling berhubungan dalam proses timbulnya respon manusia terhadap rangsangan/stimulus, yaitu: Impuls, Persepsi, Manipulasi dan Konsumasi. 1) Impuls; adalah dorongan hati (impulse) yang meliputi "stimulasi/rangsangan spontan yang berhubungan dengan alat indera" dan reaksi aktor terhadap rangsangan (respon) itu bahwa manusia berbeda dengan binatang dalam memberikan reaksi. Manusia berpikir tentang reaksi yang akan diberikan terhadap suatu stimuli dengan mempertimbangkan situasi, baik pengalaman masa lalu, situasi yang dihadapinya kini, dan mengantisipasi akibat dari tindakan di masa depan. 2) Persepsi, Manusia mempunyai kapasitas untuk merasakan dan memahami stimuli melalui pendengaran, senyuman, rasa, dan sebagainya. Persepsi melibatkan rangsangan yang baru masuk maupun citra mental yang ditimbulkannya. Aktor tidak secara spontan 
menanggapi/merespon stimuli dari luar, tetapi memikirkannya sebentar dan menilainya melalui bayangan mental. 3) Manipulasi. Manusia mempunyai beberapa kelebihan dari binatang yaitu mental dan tangan sehingga dapat memanipulasi obyek lebih cerdik daripada binatang. Tahap manipulasi merupakan tahap jeda yang penting dalam proses tindakan agar tanggapan/respon tak diwujudkan secara spontan. Sebelum melakukan tanggapan/respon terhadap obyek, manusia merenungkannya terlebih dahulu sehingga ada sela waktu. 4) Konsumasi. Respon dilakukan berdasarkan pertimbangan ini, aktor mungkin akan merespon dengan mengambil tindakan atau tidak setelah memanipulasi obyek dan memikirkan dampak yang diakibatkan oleh tindakan yang diambil.

Hal ini bila dikaitkan dengan manajmen pemasaran khususnya mengenai perilaku konsumen mengambil keputusan dijelaskan bahwa konsep perilaku konsumen menurut Shiffman dan Kanuk (2000) adalah "Consumer behavior can be defined as the behavior that customer display in searching for, purchasing, using, evaluating, and disposing of products, services, and ideas they expect will satisfy they needs". Pengertian tersebut berarti perilaku yang diperhatikan konsumen dalam mencari, membeli, menggunakan, mengevaluasi dan mengabaikan produk, jasa, atau ide yang diharapkan dapat memuaskan konsumen untuk dapat memuaskan kebutuhannya dengan mengkonsumsi produk atau jasa yang ditawarkan.

Selain itu perilku konsumen menurut Loudon dan Della Bitta (1993) adalah: "Consumer behavior may be defined as the decision process and physical activity individuals engage in when evaluating, acquiring, using, or disposing of goods and services". Dapat dijelaskan perilaku konsumen adalah proses pengambilan keputusan dan kegiatan fisik individuindividu yang semuanya ini melibatkan individu dalam menilai, mendapatkan, menggunakan, atau mengabaikan barangbarang dan jasa-jasa.
Menurut Ebert dan Griffin (1995) consumer behavior dijelaskan sebagai: "the various facets of the decision of the decision process by which customers come to purchase and consume a product". Dapat dijelaskan sebagai upaya konsumen untuk membuat keputusan tentang suatu produk yang dibeli dan dikonsumsi.

Jadi dari pendapat tersebut dapat disimpulkan bahwa perilaku konsumen adalah proses pengambilan keputusan dan kegiatan fisik individu-individu yang semuanya ini melibatkan individu dalam menilai, mendapatkan, menggunakan, atau mengabaikan barang-barang dan jasa-jasa

\section{METODE}

Penelitian ini menggunakan metode kualitatif dengan melakukan wawancara secara mendalam kepada masyarakat yang berjualan di pasar Bangkinang (pedagang pemilik toko) yang diambil secara terstruktur melalui wawancara dan dokumentasi. Data yang dikumpulkan dipaparkan menggunakan analisis deskriptif.

\section{HASIL}

Berdasarkan hasil wawancara kepada para orang tua, kemudian diperkuat oleh dukungan informasi dari putra-putri mereka diperoleh informasi bahwa faktor yang mempengaruhi mengapa orang tua berperilaku ingin menjadikannya putra putri mereka sebagai pegawai negeri sipil atau bekerja kantoran adalah sebagai berikut:

1. Prestise/Rasa Bangga

Menjadikananak-anakdariorangtua yang bukanpegawainegeridarihasilwawacarad enganpedagang retail di pasarbangkinang,

diperolehinformasiadalahsebagaibentukk ebanggaanbagi orang tua. Orang tuamerasabanggamelihatanakmerekaber pakaianseragampegawainegerisipil, terlihatgagahdanmembanggakandanbilab erjumpa orang lain ataurekanatautetangga, selaludibanggakananakmereka. 
Anaksayabekerjasebagai

PNS

dansekarangakanmenjadi

orang

besardanakandihormati.

Anak yang menjadi PNS orang tuaikutsenang,

karenaakanditanyaituanaksiapa,

makadapatdiketahuiadalahituanaksipulan, sudahmenjadipejabatsekarangdangagahdi

lihat. Selainitujugadengankondisi yang demikian

tuaakanmeningkatderajatnya

orang

kalangankerabatmerekasendiri,

karenadianggaptelahberhasilmembuatana

knyamenjadi PNS. Walaupun orang tuatidaksedikitmengeluarkanuanguntukm enyogokmenjadi PNS danterkadangada orang tua yang tertipu pula.Orang tuasanggupmenjualtanahpusakauntukmen jadikananakmerekasebagai PNS ataubekerjadikantoran.

\section{KepastianGaji}

Bekerjasebagai PNS memilikijumlahgaji yang standard ansudahbarangtentusetiapwaktunyatibaga jisudahdibayarkan. $\mathrm{Hal}$ inimenjadikepastianbagipenghasilandana kandigunakanuntukkeperluankebutuhan yang ada. Kepastianiniterkadangdapatdijadikanagun anuntukmeminjamuang di bank atausebagaiagunan.Istilahnyamenggadaik an SK. Keuntungan yang diperolehadalahmudahmendapatkanpinja mandarimenggadaikan SK danlebihdipercayapihak bank dibandingkandenganpengusahaberjualans eperti orang tuamereka.

Dari hasilwawancaradengan yang sudahmenjadi

PNS, menyebutkanbahwagaji yang diterimaterkadanghanyatinggalsisanyasaj adanselebihnyasudahuntukmembayarkred it bank.Kredit bank digunakanuntukmembelimobildankelihat angagahdanjugauntukkreditmembeliruma h.Terkadangadarasanyakepinginsepertim ereka yang punyausahasendiri.

Pernyataantersebutsudahmenjadihal yang biasa, tetapimasihsajaterusberadadalamkondisit ersebut, karenapenghasilansebagai PNS tidakhanyaberdasarkangaji yang diterimasetiapbulan, merekajugamendapatkantambahandalam bentuktambahanpenghasilanlainnyadante rkadangnilainyajauhlebihbesarbiladiband ingkandenganpendapatangajitetapnya.

\section{HariTua (Pensiun)}

Sebagai PNS mendapatkanpensiunan, walaupunkecil,

pensiunaninicukupmembantudantidakme mbuatkehidupanmenjaditerganggu.Peng hasilandaripensiunhanyagajipokoknyasaj adanitupunterkadangpembayarannyaters endat-sendat.Namunbagi orang tuaitusudahbisamenjaminkehidupanmere kasendiri.Bilabekerjasebagaipengusahate rkadangtidakmendapatkanapaapadanterkadanggagalnyalebihbanyakbil adibandingkandengankeberhasilannya.

4. Bisadiandalkan

PNS yang sudah lama bekerja dan terkadang menjadi pejabat dan ini menjadi harapan keluarga dan dapat diandalkan untuk membantu keluarga apabila ingin masuk PNS dan lainnya. Kondisi ini sangat diharapkan orang tua, sehingga karib kerabat dari keluarga akan dapat dibantunya dan akan menjadi lebih dapat diandalkan dalam keluarga itu sendiri. Selain itu, terkadang dalam menghadapi berbagai masalah yang ada selalu mereka yang PNS lebih memiliki relasi atau akses untuk menyelesaikan persoalan bila dibandingkan dengan swasta yang terkadang dipersulit.

\section{PEMBAHASAN}

Kondisi tersebut yang membuat orang tua mau bersusah payah menyekolahkan anaknya ke perguruan tinggi dan baru dikatakan berhasil apabila mereka sudah memiliki pekerjaan sebagai pegawai negeri sipil atau kerja kantoran. Apabila si anak masih belum bekerja demikian, apatah lagi mereka hanya bekerja sebagai pengusaha 
buka toko atau berkebun dan atau pekerjaan lain yang orang tuanya saja sudah bisa kerjakan tanpa sekolah, maka mereka menganggap anak mereka belum berhasil.

Walaupun terkadang hasil yang mereka peroleh dari bekerja sebagai wirausaha cukup besar dan jauh lebih besar bila dibandingkan dengan mereka bekerja sebagai PNS atau pekerja kantoran. Selain itu, bila dibandingkan juga bekerja sebagai PNS biasanya mereka menyogok sampai dengan 150 juta rupiah dan bahkan lebih baru mereka bisa masuk menjadi PNS atau pegawai kantoran. Sedangkan bila bekerja sebagai pengusaha dengan bermodal 150 juta rupiah sudah cukup besar untuk mendirikan usaha dan mengembangkannya menjadi berlipat ganda.

Selain itu juga, kekecewaan orang tua terhadap kondisi yang dirasakan dalam menyekolahkan anak mereka dan menjadi pengusaha sudah disekolahkan, dimodali mereka namun masih saja belum berhasil dan bahkan selalu menyusahkan orang tua mereka sendiri. Kekecewaan ini juga karena terkadang pendidikan yang diperoleh anak mereka diperguruan tinggi tidak sesuai dengan kebutuhan mereka berusaha, dengan istilah lain yang diajarkan lain pula yang terjadi di lapangan. Kenyataannya berbeda dari teori yang diajarkan dan ini menjadi masalah tersendiri yang dihadapi oleh mereka yang bersekolah.

Orang tua sudah jenuh dan putus asa dengan kondisi pendidikan dan juga berakibat kepada kemampuan anak mereka mencapai keberhasilan dalam berusaha. Hal ini, mereka tidak bisa berbuat banyak, karena kebanyakan dari anak-anak zaman sekarang tidak mau sekolah pada umumnya. Mereka hanya kebanyakan bermain dan kurang serius dalam belajar, ditambah lagi dengan pengaruh lingkungan yang begitu kuat. Masalah narkoba, pergaulan bebas dan kenakalan pada anak menjadi masalah masa depan yang dihadapi orang tua mendidik anak-anak mereka.

\section{SIMPULAN}

Dari uraian di atas, maka dapat ditarik kesimpulan bahwa alasan mengapa orang tua lebih menyukai anak-anak mereka menjadi PNS dibandingkan dengan menjadi pengusaha atau berwirausaha seperti mereka (orang tua) yakni menjalankan usaha membuka ruko yang ada pada pasar bangkinang antara lain: karena prestise atau rasa bangga orang tua akan hebatnya pegawai negeri sipil yakni dengan berpakaian dinas dan seragam yang apabila dilihat menjadi sebuah kebanggaan, kemudian adanya kepastian dari penghasilan disini dikaitkan bahwa walaupun gaji yang diterima mereka kecil, namun mereka mendapatkan kepastian dan ada juga tunjagannya. Bila dibandingkan dengan pengusaha tidak ada kepastian walaupun terkadang dapat besar namun kadang tidak dapat sama sekali. Juga karena adanya jaminan hari tua atau pensiunan, pensiunan menjadi masalah bagi masyarakat di daerah ini karena bila sudah pensiun penghasilan sudah terbatas dan terkadang hanya berharap dari anak yang masih belum jelas pula sehingga dengan menjadi PNS dapat ada jaminan tentang hal tersebut. Kemudian faktor bisa diandalkan, sebagai PNS atau bekerja dikantoran, maka akan lebih dapat diandalkan dalam berurusan, karena berurusan terkadang membutuhkan penampilan yang gagah dan menarik, sehingga dengan menjadi PNS dianggap dapat memudahkan berurusan dan atau menjadi orang segan. 


\section{DAFTAR PUSTAKA}

An. Ubaedy, 2007, Kompetensi kunci dalam berprestasi, career, business \& life, Bee Media Indonesia, Jakarta.

Ebert dan Griffin, 1995, Consumer Behaviour. International Edition

Ishak Arep, 2003, Manajemen Motivasi, Gramedia, Jakarta.

Kasmir, 2007, Kewirausahaan, PT RajaGrafindo Perkasa, Jakarta.

Keputusan Menteri Koperasi dan Pembinaan Pengusahan Kecil Nomor 961/KEP/M/XI/1995

Loudon dan Della Bitta, 1993, Business \& Economics

Miftah Thoha, 2008, Pembinaan Organisasi, Proses diagnose dan intervensi, RajaGrafindo Persada, Jakarta.
Ritzer, 2005, Teori Sosiologi. Kreasi Wacana : Yogyakarta

Saiman, 2009, Kewirausahaan, Teori, Praktik dan Kasus-kasus, Salemba Empat, Jakarta.

Shiffman dan Kanuk, 2000, Consumer Behavior. 7th Edition. New. Jersey

Soekanto, 2002, Teori Peranan, Jakarta, Bumi Aksara

Sopiah, 2008, Perilaku Organisasional, Andi Offset, Yogyakarta.

Taliziduhu Ndraha, 2005, Teori Budaya Organisasi, Rineka Cipta, Jakarta. 